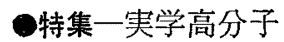

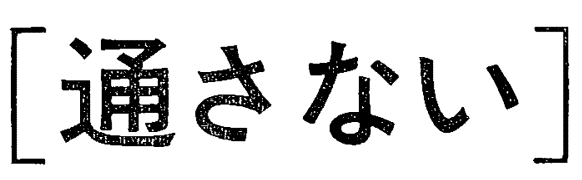

\section{岩崎 博四}

高分子材料は，多かれ少なかれ酸素や炭酸ガス，水 蒸気や有機溶媒などの気体，扤よび水，アルコールな ぞの液体を通す，このような気体や蒸気の透過性の低 いことをガスバリヤー性といい，プラスチックを大量 に使用する食品包装の分野では, その内容品飞対応し た酸素を通しにくい，ガスバリヤー性樹脂の選択が重 要である。

最近までは，セロハン，ナイロン，ポリェステル， ポリプロピレンなどを食品包装用フィルム使用する 場合は, ガスバリヤー性が劣るので, その表面にガス バリヤー性の良好なポリ塩化ビニリデンをコーティン グしていた，しかし，最近に至り，内容食品によって は，さらに高度なガスバリヤ一性を要求するょうにな り, 酸素透過係数の小さいガスバリヤー性樹脂をコー ティングの代わりに膜厚の大きいフィルムとし，これ をラミネートして使用するようになった。

\section{ガス透過}

プラスチックフィルムをガスが通る現象は古くから 知られて拉り, その透過はガスの吸着 (溶解), 拡散, 脱着の過程によって特こるとされている，酸素のよう 分子半径が比較的小さい気体の熱運動性は, 高分子 鎖のそれに比較して非常に早いため, その透過速度は 高分子鎖によって律速されるとみなされる.例宎ば， 天然ゴムの拡散係数は, 気体の分子半径が大きくなる 湮ど小さくなることが知られている1．気体の大きさ が, 高分子の熱運動槣与するセグメントの大きさに 等しいか，要るいは年的以上の場合には，高分子と気 体の両者の熱運動に依存したより複雑な機構によって 拡散すると思われる.

このように考光れば, 高分子以特ける気体の拡散,

\footnotetext{
Impermeable.
}

透過は活性化過程を通じて扣こり，この活性化状態は 気体の透過が可能な高分子鎖相互間に空孔が生成した 状態とい方る.気体は高分子鎖セグメントのまわりで 熱運動を行ない，次々之熱運動化上り形成される空孔 を通って移動すると考光られる。この空孔は固定した 孔ではなく、熱運動により大きさおよび位置が時間と ともに変動するものである。

このような空孔形成代基つくく拡散過程を考慮すれ ば, 自由体積理諭 2 により高分子中での拡散係数は, ある温度に物いて (1) 式で表わされる。

$$
D=K \cdot \exp \left[-\left(\frac{V^{*}}{V_{f}}\right)\right]
$$

すなわら，気体の移動が生じるためには，ある体積 $V^{*}$ 以上の空孔を生成することが必要であり，自由体 積 $V_{f}$ のとき沙， $V^{*}$ より大きな空孔ができる確率は $\exp \left(-V^{*} / V_{f}\right)$ に比例することになり, この確率によ って拡散が支配されるすのと考兄られる，Kは気体の 大きさ，運動速度など関する定数である。

いま,クラレの開発したエバール樹脂 ${ }^{32}$ は, エチレ ンービニルアルコール 共重合体 (EVA) であるため, $V^{*} / V_{f}$ の值は (2) 式で与えられる.

$$
\left(\frac{V^{*}}{V_{f}}\right)_{\mathrm{EVA}}=V_{\mathrm{A}}\left(\frac{V^{*}}{V_{f}}\right)_{\mathrm{A}}+V_{\mathrm{E}}\left(\frac{V^{*}}{V_{f}}\right)_{\mathrm{E}}
$$

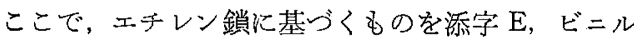
アルコール鎖に基づくものを添字 $\mathrm{A}$ で示し，也グメ ントの容積分率を $V_{\mathbf{E}}, V_{\mathbf{A}}$ で示せば，(1) 就よび (2) 式から(3) 式が得られる.

$$
D_{\mathrm{EVA}}=K \cdot \exp \left[-\left\{V_{\mathrm{A}}\left(\frac{V^{*}}{V_{f}}\right)_{\mathrm{A}}+V_{\mathrm{E}}\left(\frac{V^{*}}{V_{f}}\right)_{\mathrm{E}}\right\}\right]
$$

したがって，定数項を $K^{\prime}$ とすれば，(4) 式となる.

$$
\ln D_{\mathrm{EVA}}=\ln K^{\prime}+V_{\mathrm{A}} \ln D_{\mathrm{A}}+V_{\mathrm{E}} \ln D_{\mathrm{E}}
$$

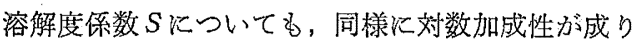
たち、かっ $P=S D$ より (5) 式となる.

$$
\ln P_{\mathrm{EV} A}=\ln \mathrm{K}^{\prime \prime}+V_{\mathrm{A}} \ln P_{\mathrm{A}}+V_{\mathrm{E}} \ln P_{\mathrm{E}}
$$
さらに,

$$
\begin{aligned}
& P_{\mathrm{EVA}}=K^{\prime \prime} \cdot P_{\mathrm{A}} V_{\mathrm{A}} \cdot P_{\mathrm{E}} V_{\mathrm{E}} \\
& \log P_{\mathrm{EVA}}=\log K^{\prime \prime}+V_{\mathrm{A}} \log P_{\mathrm{A}}+V_{\mathrm{E}} \log P_{\mathrm{E}}
\end{aligned}
$$

$V_{\mathrm{A}} \rightarrow 1, V_{\mathrm{E}} \rightarrow 0$ を考光ると $\log K^{\prime \prime}=0$ となり，(7) 式 は（8）式となる.

$$
\log P_{\mathrm{EVA}}=V_{\mathrm{A}} \log P_{A}+V_{\mathrm{E}} \log P_{\mathrm{E}}
$$

すなわり，自由体積理論により空孔形成基づく拡 散過程を考察し, 共重合体の透過係数の対数值は, 組 成の容積分率に比例して直線的に変化することが期待 される、この（8）式はEVA のようなランダム共重 合体滛験的に用いられている式と同一である4). 
Salame ${ }^{j}$ は 90 種に近い天然扣よび合成高分子のガ ス透過性について検討し，主鎖のセグメントについ て，パラメータ Permachor $\pi$ を決めて整理したとこ ろ， $25^{\circ} \mathrm{C}$ に特ける高分子の酸素透過係数 $P$ は (9) 式 でみごとに整理されることを報告している.

$$
P=6.1 \times 10^{-9} \exp (-0.115 \pi)
$$

そこで，PVA および PE の を計算し（9）式により EVAのPを計算した結果， 前報 ${ }^{3)}$ のようにェチレン含量 $30 \mathrm{~mol} \%$ 以上では契測 值と計算値はよく一致した。しかし，エチレン含量 $30 \mathrm{~mol} \%$ 以下, 特に PVA の実測値は計算值より大き かった.このことはフィルム製膜時になんらかの因子 でミクロボイドの生成拉よび PVA の製造条件による

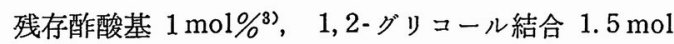
$\%^{6)}$, 短鎖分岐 $1.5 \mathrm{~mol} \%{ }^{7)}$ などの異種結合を含有す るため, PVA が本来もららるガスバリヤー性を悪く 乙, 酸素透過係数の実測値が大きくなったものと推察 される。

\section{ガス透過に及ぼす諸因子}

一般に，高分子物質のガス透過性は，極性，水素結 合, 結晶化度, 置換基, 対称性などが影響するといわ れているが, 結晶性高分子である EVAについて, こ れらの諸因子を倹討してみよう。

赤羽 ${ }^{8)}$, 松本 ${ }^{9}$ らの測定によれば, EVA の結晶化度 㹥 30〜 50\% であり，エチレン含量 $75 \mathrm{~mol} \%$ 付近で 最小になることが判明している.この結果と酸素透過 係数の值 ${ }^{3)}$ を俳せ考克れば，EVA の酸素透過係数は 結晶化度にほとんど影響されない。

EVAの結晶構造 ${ }^{8), 9)}$ は, エチレン含量 $100 \sim 80 \mathrm{~mol}$ $\%$ では PE と同様に斜方晶系で, 80〜 $60 \mathrm{~mol} \%$ は擬 六方晶系で, 50 〜 $0 \mathrm{~mol} \%$ は PVA と同様に単斜晶系 であるが, 酸素透過係数の值 ${ }^{3)}$ は結晶構造と無関係に 值線で岗る。

EVAの近赤外吸収スペクトル102 は，エチレン含量 の増大とともに分子内 $(1.49 \mu)$ 拈よび分子間水素結 合 $(1.58 \mu)$ 㥀線的に， かつ平行に低下しているこ とより，酸素透過係数の值は水素結合とは相関性があ るようである。

これらの考察から，高分子のガス透過性を決定する 因子は，極性および極性に基づく水素結合であると推 察される.このように教察すると, Salamenの machor $\pi$ と極性のパラメータである溶解性パラィー

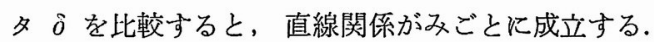

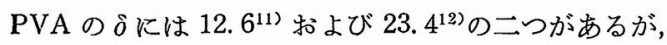
極性を考察する場合には後者が適切なようである.

紙面の都合で, 種々の関係を図示できなかったが，
引用文献を末尾に記したので，読者の各位において考 察し，ご意見を賜われば幸甚です。

\section{文献}

1) Van Amerongen : J. Polym. Sci., 5, 307 (1950)

2) M. H. Cohen, D. Turnbull, : J. Chem. Phys., 31, 1164 (1959)

3) 岩崎博四, 帆足與次：高分子論文集， 34, 785 (1977)

4) A. E. Barnabeo, W. S. Creasy, L. M. Robeson: J. Polym. Sci., Polym. Chem. Ed., 13, 1979 (1975)

5) M. Salame : ACS Polymer Preprints, 8 [1] 137 (1967)

6) 井本二郎, 浮田純二, 小南次夫 : 高分子化学, 14, 101，214 (1959)

7) R. L. Adelman, R. C. Ferguson : J. Polym. Sci., 13, 891 (1975)

8）赤羽拨志，望月隆化：高分子化学, 28,577 (1971)

9) 松本恒隆, 中前勝彦, 小越信昭, 川添正志, 岡 英明：同上, 28, 610 (1971)

10）赤羽健志：未発表

11) J. Brandrup, E. Immergnt : Polym. Handbook, V-341 (1967)

12) 高分子学会編：高分子工学講座，13，169 (1967)

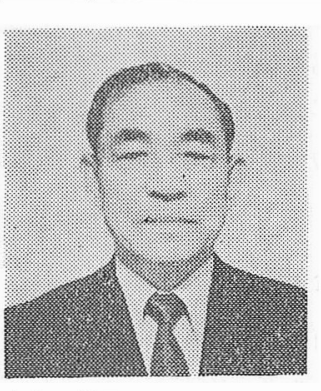

岩崎 博四

こいわさき ひろし
(株)クラレ 生産本部(530 大阪市北区梅田 1-12） 本 部長補佐

昭和20年九州大学工学部応 用化学科卒. 同年クラレ入 社, 現在に至る. 51年高分 子学会賞 (技術部門) 受賞. 〈趣味〉 サッカー, 園芸 